\title{
Production and marketing of semi organic rice in Bantul Regency Special Region of Yogyakarta
}

\author{
Eni Istiyanti ${ }^{*}$, Salmah Umi Badriyah, and Reza Raditya Rachman \\ Department of Agribusiness, Faculty of Agriculture, Universitas Muhammadiyah Yogyakarta, \\ Indonesia
}

\begin{abstract}
Semi-organic rice farming utilizes natural ingredients and considers ecological and health factors but still uses chemicals in a small proportion. It has become a transition to organic rice farming. This research aims to analyze the production costs, income, profit, and feasibility of farming, identify marketing channels, and analyze the marketing efficiency of semi-organic rice in Bantul Regency. A total of 60 semi-organic rice farmers were selected using the Multistage Random Sampling method, while 11 traders were obtained based on the Snowball method. The farming feasibility analysis was based on Revenue Cost Ratio $(\mathrm{R} / \mathrm{C})$ and Break Even Point (BEP) criteria, while the marketing efficiency analysis was based on Technical Efficiency Index (TEI) and Economic Efficiency Index (EEI). The results uncovered that with a land area of $2,000 \mathrm{~m}^{2}$, semi-organic rice farming incurred production costs of IDR $4,319,801$, generating an income of IDR 4,590,438 and profit of IDR 2,245,817. Semi-organic rice farming in Bantul Regency was feasible based on the $\mathrm{R} / \mathrm{C}$ and BEP criteria. There were seven marketing channels for semi-organic rice in Bantul Regency, and on all channels, the farmer's share was $>50 \%$. Marketing channel IV was the most efficient channel, both technically and economically.
\end{abstract}

\section{Introduction}

Most of the rice farming developed in Indonesia is non-organic rice, in which the farming activities use chemicals as production inputs. Farmers use chemicals in the form of pesticides and fertilizers to increase rice production. Unfortunately, the use of chemicals in the long term can have a negative and detrimental impact on society, especially in terms of health. In addition, it can have adverse side effects on agricultural land, namely a decrease in soil productivity and damage to the balance of the ecosystem [1].

Public awareness of the dangers of chemicals to health and the environment encourages the development of an environmentally sound and sustainable agricultural system called organic farming [2]. Organic farming is an agricultural system that uses natural ingredients and without chemicals. This agricultural system must pay attention to the principles of

* Corresponding author: eniistiyanti@umy.ac.id 
ecology, health, justice and protection of the environment [1]. The development of organic rice in Indonesia is still limited due to various obstacles, including; lack of understanding of organic philosophy among farmers, inconsistent supply in terms of quality, quantity, continuity, and the authenticity of organic products (certification required), and the absence of apparent market certainty [3].

The change from non-organic rice to organic rice farming requires a transition period called semi-organic rice farming, as it still uses chemical fertilizers and pesticides, although in small quantities. Basically semi-organic rice is almost the same as inorganic (nonorganic) rice, in which the difference lies in the selection of varieties and the basis of fertilization [4]. Semi-organic rice farming still ignores the sterility of irrigation and the surrounding environment [5].

Organic rice farming in Bantul Regency is in the transition period, namely semi-organic rice farming. It is because the location and geographical condition of this regency is a downstream area, so that the water flowing for irrigation has been polluted with residues of chemical fertilizers and industrial and household waste. Agricultural land areas are also on the roadside, causing plants to be exposed to air pollution from various vehicles. In addition, organic rice plots are still side by side with non-organic land plots, resulting in contamination from land using chemical fertilizers and pesticides [6].

Based on the Indonesian Organic Alliance (AOI) data, the area of organic agricultural land is around 50,000 ha or $0.2 \%$ of all Indonesian agricultural land [7]. Organic farming encourages farmers to be more environmentally responsible by avoiding the use of chemicals. The price of chemical fertilizers and pesticides is getting more expensive, encouraging farmers to look for cheaper and easier alternatives, always available, and abundant, namely organic or natural ingredients. Farmers can make their organic fertilizers and pesticides this reducing input farming costs.

Marketing of organic and semi-organic rice has differences from non-organic rice, especially regarding the quality and price. Organic and semi-organic agricultural products have good prospects for both domestic and global markets [8]. The middle and upper economic groups still dominate the market share of organic and semi-organic agricultural products in Indonesia due to the lack of information, knowledge, and understanding of organic products and the relatively expensive price [7].

Most semi-organic rice farmers in Bantul Regency use manure from their livestock or neighbors. Organic pesticides are also made using plants around the house, such as "intaran" leaves or tobacco. Farmers sell the harvest in the form of grain to traders or rice mills. The price received by farmers in selling semi-organic rice is relatively the same as the price of non-organic rice, although the price is different at the consumer level. This study analyzed production aspects, including analyses of production costs, income, profits, and feasibility of farming and marketing aspects, including marketing channels, marketing margins, and marketing efficiency. It is different from previous studies, which generally only discussed one aspect, namely production or marketing, as carried out by [9] and [10] which examined aspects of organic rice production [11], [12] and [13]. This study aimed to analyze the production costs, income, profitability, and feasibility of farming and examine the costs, margins, and marketing efficiency of semi-organic rice in Bantul Regency, Special Region of Yogyakarta.

\section{Research Method}

The research was conducted in Bantul Regency based on the consideration that $40 \%$ of its districts have implemented semi-organic rice farming [14]. The sampling of farmers was carried out using the Multistage Random Sampling method, a process of taking samples in stages starting from the district to the farmer group members. 


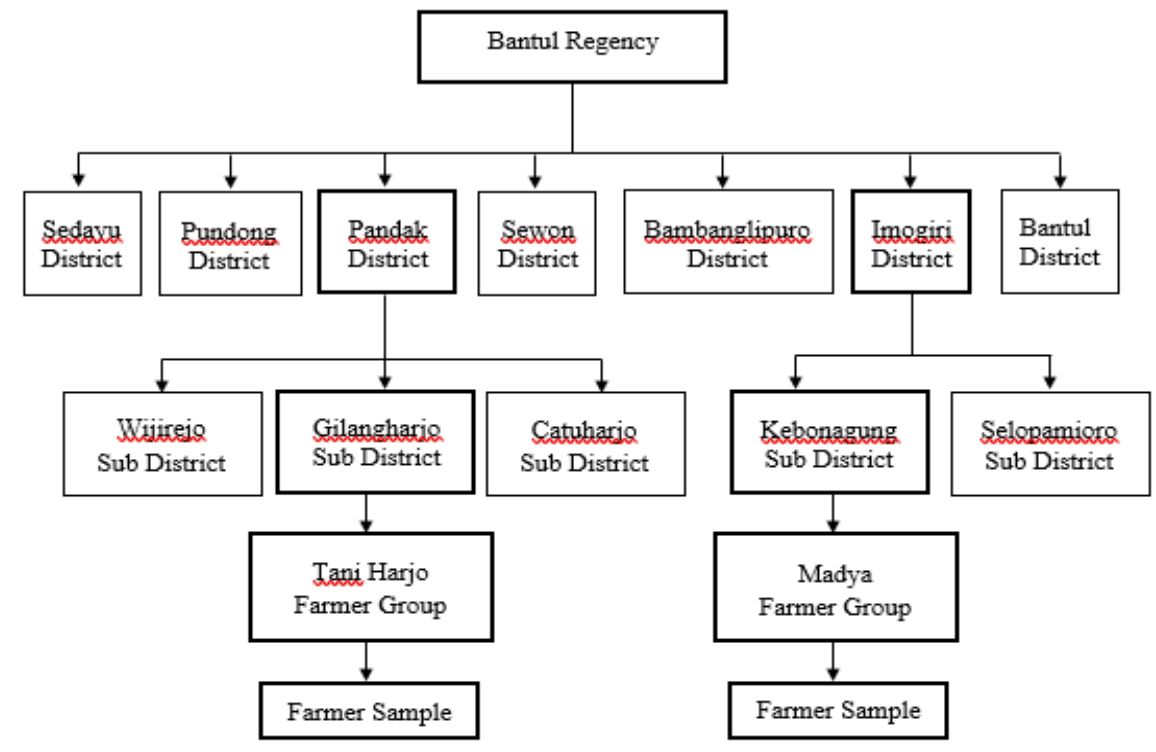

Fig. 1. Stages of taking research samples using the Multistage Random Sampling method.

The sample of farmers was 60 people, who were members of the Tani Madya and Tani Harjo farmer groups, 30 farmers each. The sampling of traders employed the Snowball method based on information from farmer and trader respondents. The number of traders involved in the semi-organic rice marketing process in Bantul Regency was 11 people consisting of collector merchants, rice millers, collecting traders, and retailers.

This study utilized primary data obtained through interviews with farmers and traders based on a list of questions prepared and secondary data gathered through documentation from related agencies, namely the village and district offices, Agricultural Extension Center (BPP), and the Regional Development Planning Agency (Bappeda). Primary data included the identity of farmers and traders, the use and price of production factors, the production and price of semi-organic rice, milling costs, packaging costs, transport costs, and other marketing costs.

Descriptive data analysis aimed to determine production costs, income, and profits of semi-organic rice farming. Production costs consisted of explicit costs - incurred to obtain production factors used in the production process and implicit costs - estimates of the value of the farmers' production factors. Revenue is the multiplication between production and product prices. Net revenue or income is the difference between revenue and explicit costs, while profit is the difference between revenue and total costs consisting of explicit and implicit costs [15], mathematically written as follows

$$
\begin{gathered}
T C=T E C+T I C \\
N R=T R-T E C \\
\pi=T R-T C
\end{gathered}
$$

Description:

$\mathrm{TC}=$ Total Cost

TEC $=$ Total Explicit Cost

TIC $=$ Total Implicit Cost

$\mathrm{NR}=$ Net Revenue

$\mathrm{TR}=$ Total Revenue

$\pi \quad=$ Profit 
The feasibility analysis was based on the Revenue Cost Ratio $(\mathrm{R} / \mathrm{C})$ criteria, namely the comparison between total revenue and total costs and the Break Even Point (BEP) price and production volume. Semi-organic rice farming is feasible if $\mathrm{R} / \mathrm{C}>1$, semi-organic rice price $>$ BEP price and the amount of semi-organic rice production $>$ BEP volume.

$$
\begin{gathered}
R / C=T R / T C \\
\text { BEP price }=T C / \text { production } \\
\text { BEP volume }=T C / \text { price }
\end{gathered}
$$

Description: $\mathrm{R} / \mathrm{C}=$ Revenue Cost Ratio

$$
\mathrm{BEP}=\text { Break Even Point }
$$

Marketing costs, margins and profits were analyzed descriptively. Marketing costs are costs incurred by marketing agencies during the marketing process [16]. The more marketing institutions, the more treatment is given to the products to be marketed, thus increasing the marketing costs [17]. The marketing costs of each marketing agency can be written as follows:

$$
V=V T r+V P c k+V P o+V S o+V B m a+V P r
$$

Description:

$\mathrm{V} \quad$ : Marketing costs for semi-organic rice for each marketing agency

VTr : Transportation costs

VPck: Packaging costs

VPo : Processing costs

VSo : Sorting costs

VBma: Loading and unloading costs

VPr : Levy taxes costs

Marketing margin is the difference between the price paid by consumers and the price received by producers (farmers) on each marketing channel [18] shows the price difference between marketing agencies in a marketing channel. The marketing margin of each marketing agency can be formulated as follows:

$$
M p=P j l-P b l
$$

Description:

Mp : Marketing margin of semi-organic rice for each marketing agency (IDR/kg)

$\mathrm{Pjl}$ : Selling price of semi-organic rice at the next level of marketing agency (IDR/ $\mathrm{kg}$ )

$\mathrm{Pbl}$ : Purchase price of semi-organic rice at the previous marketing agency level (IDR/kg)

Marketing profit is the difference between marketing margin and marketing costs in each institution on each channel mathematically written as follows:

$$
\pi=M p l-V l
$$

Description:

$\pi \quad$ : Marketing profit of semi-organic rice for each marketing agency (IDR/kg)

$\mathrm{Mpl}$ : Marketing margin for semi-organic rice for each marketing agency (IDR/kg)

$\mathrm{Vl}$ : Marketing costs for semi-organic rice for each marketing agency (IDR/kg)

Farmer's share is a percentage share of the price received by farmers or a comparison of prices at the farm level with prices paid by consumers. The share size of the price received 
by farmers, shows whether or not the distribution of sales results by each other marketing agency to farmers is fair [19].

Description:

$$
\text { Farmer's Share }(F S)=(P f / P r) 100 \%
$$

Pf : Farmer price

$\operatorname{Pr}$ : Consumer price

Marketing efficiency can be seen based on the Technical Efficiency Index (TEI) and Economic Efficiency Index (EEI) for each marketing channel [13]. Based on the TEI and EEI values, it can be seen which marketing channel is the most efficient. TEI and EEI can be searched based on the following formula:

$$
\begin{gathered}
T E I=V i j / d \\
E E I=\pi j k / V i j
\end{gathered}
$$

Description:

TEI : Technical Efficiency Index

EEI : Economic Efficiency Index

Vij : Total marketing costs (IDR/kg)

$\pi \mathrm{jk}$ : Profit per marketing channel (IDR/kg)

d : Tke distance traveled by each marketing channel $(\mathrm{km})$

i : Semi-organic rice commodity

j : Marketing channel

$\mathrm{k}$ : Marketers

\section{Results and Discussion}

\subsection{Profile of semi-organic rice farmers and traders}

The semi-organic rice farmers used as respondents were members of the farmer groups "Tani Harjo" in Pandak District and "Tani Madya" in Imogiri District, Bantul Regency. Table 1 exhibits that more than $80 \%$ of semi-organic farmers are over 50 years with an average age of 60.8 years. Semi-organic rice farmers in Bantul are older than those in Nepal, with an average age of 44.85 years [10] and Sleman, with an average age 54.5 [20] Relatively old age did not become an obstacle for farmers to do semi-organic rice farming because workers outside the family carried out heavy activities such as land processing and planting [21].

Regarding the level of education, more than $75 \%$ of farmers have formal elementary and junior high school education. It is similar to the education level of organic rice farmers in West Bandung Regency, where most had elementary and junior high school education [22]. In order to increase farmers' knowledge and skills related to agriculture, they can take courses, training, or search for information in print and electronic media [23].

The average experience of farmers in semi organic rice farming was 10.5 years, and this situation was associated with the government policy of "Go Organic" in 2010. The government has made several efforts to encourage farmers to implement organic rice farming, including conducting training and socialization of organic rice farming systems and organic fertilizer assistance. As many as $20 \%$ of farmers have implemented semiorganic rice farming for more than 20 years because they have livestock of which the manure can be used as fertilizer. 
Table 1. Profile of semi-organic rice farmers in Bantul Regency.

\begin{tabular}{|l|c|c|}
\hline \multicolumn{1}{|c|}{ Description } & Number (person) & Percentage (\%) \\
\hline Age (years) & 10 & 16.67 \\
$39-50$ & 23 & 38.33 \\
$51-62$ & 20 & 33.33 \\
$63-74$ & 7 & 11.67 \\
$75-86$ & & \\
\hline Education & 36 & 60.00 \\
\hline Elementary school & 10 & 16.67 \\
Junior high school & 12 & 20.00 \\
High school & 2 & 3.33 \\
College & & \\
\hline Farming Experience (years) & 30 & 50.00 \\
\hline$<6$ & 16 & 26.67 \\
$6-13$ & 8 & 13.33 \\
$14-21$ & 1 & 1.67 \\
$22-29$ & 5 & 8.33 \\
$>29$ & & 35.00 \\
\hline Land Area (m ${ }^{2}$ ) & 21 & 33.33 \\
\hline$<1,000$ & 20 & 18.33 \\
$1,000-1,999$ & 11 & 13.33 \\
$2,000-2,999$ & 8 & 60.00 \\
$>3,000$ & \multicolumn{2}{|c|}{} \\
\hline Land Status & 36 & 20.00 \\
\hline One's own & 4 & 3.33 \\
Rent & 12 & 10.00 \\
Profit-sharing & 2 & \\
Own and rent & 6 & \\
Own and profit-sharing & \multicolumn{2}{|c|}{} \\
\hline
\end{tabular}

Based on the land area for farming, $68 \%$ of farmers farm semi-organic rice on land less than $2,000 \mathrm{~m}^{2}$ with an average land area of $1,541 \mathrm{~m}^{2}$. The land for semi-organic rice farming in Batul Regency is narrower than in Sragen Regency 4,600 $\mathrm{m}^{2}$ [24]. The farmers also own the land used for semi-organic rice farming, but $27 \%$ of them farm in land belonging to other people by renting or profit-sharing. Even though they did not own land, they were passionate about growing semi-organic rice.

There were 11 semi-organic rice marketing institutions in Bantul Regency consisting of collector merchants ( 2 people), collecting traders ( 2 people), rice millers ( 2 people), and retailers (5 people). All marketing agencies were productive age, meaning they are in excellent physical condition and responsive to any changes or innovations [25]. The majority had a high school education, and some even had a bachelor's degree, totalling $30 \%$. A relatively high level of education would ease marketing agencies to carry out their business activities. Semi-organic rice marketing institutions have had a long enough trading experience, with an average of 12 years. This long experience can facilitate and assist them in developing semi-organic rice trading businesses in the future.

\subsection{The farming analysis of semi-organic rice}

The costs of semi-organic rice farming consist of explicit costs, including costs of production facilities, labor outside the family, depreciation of equipment, land rent, and others, as well as implicit costs comprising costs of family labor, rent of own land and interest on own capital. 
Table 2. Costs of semi-organic rice farming in Bantul Regency for a land area of 2,000 $\mathrm{m}^{2}$

\begin{tabular}{|l|r|r|}
\hline \multicolumn{2}{|c|}{ Description } & \multicolumn{2}{c|}{ Cost (IDR) } \\
\hline Explicit Costs & 67,777 & 1.57 \\
\hline Land rental fee & 171,922 & 3.98 \\
\hline Tool depreciation cost & 57,407 & 1.33 \\
\hline Seed & 174,572 & 4.04 \\
\hline Manure & 3,028 & 0.07 \\
\hline Liquid organic fertilizer & 41,120 & 0.95 \\
\hline Factory organic fertilizer & 185,341 & 4.29 \\
\hline Chemical fertilizer & 23,030 & 0.53 \\
\hline Chemical pesticides & $1,152,174$ & 26.67 \\
\hline Labor outside the family & 98,810 & 2.29 \\
\hline Miscellaneous expense & $1,975,181$ & 45.72 \\
\hline Total explicit cost & \multicolumn{2}{|c|}{} \\
\hline Implicit Cost & 755,104 & 17.48 \\
\hline Own land rent & 49,513 & 1.15 \\
\hline Own seed & 360,981 & 8.36 \\
\hline Own manure & 34,988 & 0.81 \\
\hline Foliar fertilizer & 58,836 & 1.36 \\
\hline Organic Pesticides & 40,413 & 0.94 \\
\hline Interest on own capital modal & $1,044,785$ & 24.19 \\
\hline Costs of family labor & $2,344,620$ & 54.28 \\
\hline Total implicit cost & $4,319,801$ & 100.00 \\
\hline Total cost & &
\end{tabular}

Table 2 displays that labor costs, both outside and within the family, have the largest proportion than other costs. Activities requiring quite a lot of labor were harvesting, land processing, and planting. It is similar to organic rice farming in Cambodia [26]. Wages for land farming and semi-organic rice farming in Bantul were paid on a wholesale basis based on land area, while harvest wages were generally given in the form of grain, which was one-tenth of the total yield. The labor costs of semi-organic rice farming are greater than in Pringsewu Regency [27].

The manure costs had a fairly large proportion, both from livestock owned by the farmers and purchased. The average use of manure was $600 \mathrm{~kg} / 2,000 \mathrm{~m}^{2}$ at a price of IDR $800 / \mathrm{kg}$. Manure was given in stages three times, namely when the land was processed as basic fertilizer, the second was when the plants were 30 days old, and the third was when the plants were 45 days old. In organic rice farming, manure is the main fertilizer because it contains elements of $\mathrm{N}, \mathrm{P}, \mathrm{K}$, and $\mathrm{C}$ with a ratio between $\mathrm{C}$ and $\mathrm{N}$ of about $40 \%$, needed by rice plants [28]. Moreover, manure also improves physical properties, soil chemistry and biology [29].

Table 3 demonstrates that the semi-organic rice production in Bantul Regency reaches $1,081 \mathrm{~kg} / 2,000 \mathrm{~m}^{2}$ or $5,405 \mathrm{~kg} / \mathrm{ha}$ of milled dry grain. It is lower than the production in Sragen, reaching 6 tons/ha [9] but higher than in the Philippines, reaching only 3,250 kg/ha [30]. The income of semi-organic rice farming on $2,000 \mathrm{~m}^{2}$ land is IDR 4,590,438 or IDR $23,000,000 /$ ha. This high income was due to the relatively low explicit costs because most of the inputs were owned by the farmers, such as manure, organic pesticides, and family labor. Organic rice farming income in Bantul Regency is greater than in Pesawaran Regency [31] but lower than that for Integrated Crop Management Field School (SLPTT) participating farmers in Pringsewu Regency [27]. 
Table 3. Income, profit, $\mathrm{R} / \mathrm{C}$ and $\mathrm{BEP}$ of semi-organic rice farming in Bantul for a land area of $2,000 \mathrm{~m}^{2}$

\begin{tabular}{|l|r|}
\hline \multicolumn{1}{|c|}{ Description } & \multicolumn{2}{|c|}{ Value } \\
\hline Production (kg) & 1,081 \\
\hline Price (IDR/kg) & 6,073 \\
\hline Revenue (IDR) & $6,556,618$ \\
\hline Explicit Costs (IDR) & $1,975,181$ \\
\hline Implicit Costs (IDR) & $2,344,620$ \\
\hline Income (IDR) & $4,590,438$ \\
\hline Profit (IDR) & $2,245,817$ \\
\hline R/C & 1.52 \\
\hline BEP price (IDR) & 3,996 \\
\hline BEP volume (kg) & 711.3 \\
\hline
\end{tabular}

Based on the feasibility analysis, the $\mathrm{R} / \mathrm{C}$ value of semi-organic rice is 1.52 , meaning that every IDR 1 of the costs incurred will receive a revenue of IDR 1.52. The R/C value of semi-organic rice in Bantul Regency is smaller than in the Philippines, which was 2.77 [30] and Pringsewu Regency, Lampung, which was 3.27 [27]. Semi-organic rice production is greater than BEP volume, and price of semi-organic rice greater than BEP price, implying that semi-organic rice farming is profitable. The same situation occurs in organic rice farming and the LEISA system in the Philippines [30].

\subsection{Marketing analysis of semi-organic rice farming}

In marketing their products, semi-organic rice farmers in Bantul Regency used seven marketing channels involving marketing institutions of rice millers, collector merchants, collecting traders, and retailers. The products sold by farmers were harvested dry rice, milled dry rice, or rice, depending on the marketing agency buying it. The conversion from milled dry unhulled rice to rice was $65 \%$, while from harvested dry unhulled rice to rice was $50 \%$. This shrinkage occurred due to physical damage to the grain, the reduced water content in the grain, and the stripping of the husk of the grain at the time of milling [32]. Rice millers and collector merchants were willing to accept harvested and milled dry rice, while collecting traders accepted milled dry rice only, which were then ground into rice to be sold to retailers or consumers.

Table 4. Distribution of semi-organic rice farmers by marketing channel.

\begin{tabular}{|c|l|c|c|}
\hline No & \multicolumn{1}{|c|}{ Marketing Channel } & $\begin{array}{c}\text { Number of Farmers } \\
\text { (people) }\end{array}$ & Percentage (\%) \\
\hline I & $\begin{array}{l}\text { Farmers - Millers - Retailers - } \\
\text { Consumers }\end{array}$ & 9 & 15 \\
\hline II & Farmer - Millers - Consumers & 12 & 20 \\
\hline III & $\begin{array}{l}\text { Farmers - Collecting Traders - } \\
\text { Retailers - Consumers }\end{array}$ & 12 & 20 \\
\hline IV & $\begin{array}{l}\text { Farmers - Collecting Traders - } \\
\text { Consumers }\end{array}$ & 5 & 18.33 \\
\hline V & $\begin{array}{l}\text { Farmers - Collector Merchants - } \\
\text { Retailers - Consumers }\end{array}$ & 11 & 10 \\
\hline VI & $\begin{array}{l}\text { Farmers - Collecting Merchants - } \\
\text { Consumers }\end{array}$ & 6 & 8.33 \\
\hline VII & Farmers - Consumers & 5 & 100 \\
\hline & Amount & 60 & \\
\hline
\end{tabular}


Channels II and III were mostly chosen by farmers. On channel II, farmers merely had to deliver the newly harvested grain to a mill not far from where they lived, namely in Kebon Agung Village, Imogiri District, Bantul Regency. The rice mill carried out the drying and processing of grain into rice for further sale to consumers. Channel III was also in demand by farmers because they did not need to incur transportation costs since the collecting traders took the grain at the farmers' houses and then ground it into the rice and sold it to retailers. Some farmers marketed their semi-organic rice directly to consumers after grinding their grain to a rice mill.

There are more semi-organic rice marketing channels in Bantul Regency than in Lampung, with solely three channels [11] and Sragen Regency, with four channels [12]. Most semi-organic rice farmers in Bantul Regency marketed their products to three marketing institutions: rice millers, collecting traders, and collector merchants, although some farmers sold them directly to consumers. Collecting traders took the rice from farmers' houses, while collector merchants received the rice delivered by farmers at their houses.

Table 5 reveals that the smallest marketing cost occurs on channel VII, where farmers directly sell the rice to consumers without going through a marketing agency. Farmers incur rice marketing costs of IDR $750 / \mathrm{kg}$ for milling and transportation costs. The biggest marketing cost is on channel V, IDR $1,710 / \mathrm{kg}$, as it involves marketing agencies of collector merchants and retailers. Collector merchants incurred the costs of transportation, loading and unloading, drying, milling, sorting, and packaging. In other words, these many activities caused the large marketing costs spent by marketing agencies [18]. Retailers on channel $\mathrm{V}$ did not incur marketing costs because their activity only sold the rice to consumers.

Table 5. Cost, margin, profit, and farmer's share of semi-organic rice marketing in Bantul Regency

\begin{tabular}{|c|c|c|c|c|c|c|c|}
\hline \multirow[t]{2}{*}{ Marketing Agency } & \multicolumn{7}{|c|}{ Semi Organic Rice Marketing Channel } \\
\hline & $\mathbf{I}$ & II & III & IV & $\mathbf{V}$ & VI & VII \\
\hline \multicolumn{8}{|l|}{\begin{tabular}{|l} 
Marketing Cost (IDR/kg) \\
\end{tabular}} \\
\hline Farmers & 307 & 308 & 160 & 160 & 310 & 298 & 750 \\
\hline Collecting traders & & & & & 1,400 & 1,400 & \\
\hline Collector merchants & & & 1,400 & 1,500 & & & \\
\hline Millers & 950 & 1,000 & & & & & \\
\hline Retailers & 450 & & & & & & \\
\hline Total & 1,707 & 1,308 & 1,560 & 1,660 & 1,710 & 1,698 & 750 \\
\hline Marketing Margin (IDR/kg) & & & & & & & \\
\hline Collecting traders & - & - & - & - & 3,817 & 5,062 & - \\
\hline Collector merchants & & - & 3,192 & 4,131 & & - & - \\
\hline Millers & 3,328 & 4,647 & - & - & - & - & - \\
\hline Retailers & 2,000 & & 1,500 & - & 3,000 & - & - \\
\hline Total & 5,328 & 4,647 & 4,692 & 4,131 & 6,817 & 5,062 & $\mathbf{0}$ \\
\hline Marketing Profit (IDR/kg) & & & & & & & \\
\hline Collecting traders & - & - & - & - & 2,107 & 3,364 & - \\
\hline Collector merchant & - & - & 1,632 & 2,471 & - & - & - \\
\hline Millers & 2,071 & 3,339 & - & - & - & - & - \\
\hline Retailer & 1,550 & - & 1,500 & - & 3,000 & - & - \\
\hline Total & 3,621 & $\mathbf{3 , 3 3 9}$ & 3,132 & 2,471 & $\mathbf{5 , 1 0 7}$ & 3,364 & $\mathbf{0}$ \\
\hline Farmer's Share (\%) & 64 & 66.8 & 69 & 72 & 60 & 66 & 94 \\
\hline
\end{tabular}

The largest marketing margin for semi-organic rice is on channel $\mathrm{V}$, because the costs and profit of marketing agencies are the largest than other channels. Marketing channel IV has a margin of IDR $4,131 / \mathrm{kg}$ of rice, thus being the marketing channel with the lowest margin. It is because channel IV only involves one marketing agency, namely the collecting 
traders, where the marketing costs incurred, and the profit obtained by the collecting traders are relatively low. Marketing costs incurred by collecting traders on this channel are IDR $1,600 / \mathrm{kg}$, used for transportation, loading and unloading activities, milling, packaging, and sorting, while the profit earned is IDR $2,471 / \mathrm{kg}$. The marketing margin of semi-organic rice in Bantul Regency is greater than in Sinobai District, Rokan Hilir Regency, which was IDR $1,050 / \mathrm{kg}$ [33].

All semi-organic rice marketing channels in Bantul Regency have a farmer's share greater than $50 \%$, thus the marketing channel is efficient [31]. Based on the marketing channel that involves channel IV marketing institutions, the farmer's share is the highest where the selling price of farmers is IDR 10,369 while the consumer's buying price is IDR 14,500 so that the farmer's share is $72 \%$. This means that $72 \%$ of the price is paid to farmers, while $28 \%$ of the price is paid to marketing institutions, namely collectors. Semiorganic rice collector traders incur small marketing costs and take relatively low profits. Farmer's share of semi-organic rice in Bantul Regency is greater than farmer's share of rice in the traditional market of Ciamis Regency, West Java, which was 67.5\% [17] but lower than the highest farmer's share in Lampung [11].

Table 6. Marketing efficiency of semi-organic rice in Bantul Regency.

\begin{tabular}{|l|r|r|r|r|r|r|r|}
\hline \multirow{2}{*}{ Description } & \multicolumn{1}{|c|}{ Semi-Organic Rice Marketing Channel } \\
\cline { 2 - 8 } & \multicolumn{1}{|c|}{ I } & \multicolumn{1}{|c|}{ II } & \multicolumn{1}{|c|}{ IV } & \multicolumn{1}{c|}{ V } & \multicolumn{1}{c|}{ VII } \\
\hline Cost (IDR/kg) & 1,707 & 1,308 & 1,560 & 1,660 & 1,710 & 1,698 & 750 \\
Profit (IDR/kg) & 3,621 & 3,339 & 3,132 & 2,471 & 5.107 & 3,364 & 0 \\
Distance (km) & 2.7 & 1.0 & 4.6 & 10.2 & 9.4 & 9.8 & 1.6 \\
TEI (IDR/km) & 640.29 & 1,348 & 336 & 162.51 & 182.52 & 174.20 & 471.70 \\
EEI & 2.12 & 2.55 & 2.01 & 1.49 & 2.99 & 1.98 & 0 \\
\hline
\end{tabular}

Marketing is considered efficient, if it meets two conditions: able to deliver agricultural products from farmers as producers to consumers at the lowest possible cost, and able to hold a fair distribution of the total price paid by final consumers to all parties involved in the production and marketing process of these products [34]. Table 6. depicts that the most technically efficient marketing channel is channel IV, with a Technical Efficiency Index (TEI) value of 162.51. It indicates that every delivery of semi-organic rice with a distance of one kilometer will cost IDR 162.51. It was influenced by the distance between farmers and collecting traders, while the marketing costs incurred were similar to other channels.

The channel IV was also the most economically efficient marketing channel of the seven existing semi-organic rice marketing channels. An Economic Efficiency Index (EEI) value of 1.49 means that for every one IDR of marketing costs incurred, a profit of 1.49 IDR will be obtained. In this case, marketing institutions distributed semi-organic rice, which did not cost much, but still earned decent profits. Channel IV with one marketing agency, namely collecting traders, was technically and economically the most efficient channel. The size of the Technical Efficiency Index is influenced by marketing costs incurred and the distance travelled, and the Economic Efficiency Index is affected by marketing costs incurred and the marketing benefits obtained at each marketing agency [13].

\section{Conclusions and suggestions}

Semi-organic rice farming in Bantul Regency provided high income for farmers and was feasible to farm based on $\mathrm{R} / \mathrm{C}$ criteria and Break Even Point. There were seven semiorganic rice marketing channels. Channel IV involving one marketing agency, the collecting traders, had the smallest marketing margin and the highest farmer's share, and became the most efficient technically and economically. 
The income of semi-organic rice farming in Bantul Regency can still be increased by reducing the use of chemical fertilizers and processing their manure. Reducing chemical fertilizers and production costs will encourage semi-organic rice farming to become organic rice to increase the rice quality and the price. Assistance to semi-organic farmers in the manufacture of organic fertilizers and pesticides and farming techniques is highly required to achieve "go organic" in Bantul Regency.

Acknowladgment. The writers would like to express gratitude to the Publication, Research and Community Service Institute (LP3M) of Universitas Muhammadiyah Yogyakarta for providing funds for this research.

\section{References}

1. H. Mayrowani, Forum Penelit. Agro Ekon. 30, 91 (2016).

2. M. Vassalos, C. R. Dillon, and P. Karanikolas, in Role Knowledge, Innov. Hum. Cap. Multifuncional Agric. Rural Dev. (Belgrade, Republic of Serbia, 2009).

3. M. Arbi, T. Thirtawati, and Y. Junaidi, JSEP (Journal Soc. Agric. Econ. 11, 22 (2018).

4. N. Rahmawati and T. Triyono, Agrar. J. Agribus. Rural Dev. Res. 3, (2017).

5. S. Yadi, S. Budi, and Sudrajat, J. Ilm. Mhs. Agroinfo Galuh 7, 71 (2020).

6. N. Ratmawati, T. Triyono, and S. Sriyadi, SEPA J. Sos. Ekon. Pertan. Dan Agribisnis 12, 19 (2017).

7. Borgumono, Pertanian Organik Solusi Alternatif Pertanian (Yogyakarta, 2016).

8. I. P. Tarwendah, J. Pangan Dan Agroindustri 5, 66 (2017).

9. R. Sukristiyonubowo, H. Wiwik, A. Sofyan, H. . Benito, and S. De Neve, Int. Res. J. Agric. Sci. Soil Sci. 1, 172 (2011).

10. R. K. Adhikari, J. Agric. Environ. 12, 97 (2011).

11. M. I. Affandi and S. Handayani, J. Phys. Conf. Ser. 1500, (2020).

12. A. N. Ulfa and Masyhuri, Agro Ekon. 29, 287 (2018).

13. M. Yunus and H. Syahputra, J. Manaj. Teknol. 12, 195 (2013).

14. Departemen Pertanian DIY, Statistik Tanaman Pangan (Badan Pusat Statistik, Daerah Istimewa Togyakarta, 2017).

15. Agustina Shinta, Ilmu Usahatani (Universitas Brawijaya Press, 2011).

16. S. B. Verma, Agricultural Marketing, India (Scientific Publishers, 2017).

17. E. Suminartika and I. Djuanalia, Mimb. AGRIBISNIS J. Pemikir. Masy. Ilm. Berwawasan Agribisnis 3, 13 (2017).

18. A. E. Saragih and N. Tinaprilla, Forum Agribisnis 5, 1 (2017).

19. E. Istiyanti, J. Pertan. MAPETA 12, 116 (2011).

20. Triyono, in Third Int. Conf. Sustain. Innov. 2019 - Humanit. Educ. Soc. Sci. (IcoSIHESS 2019) (Yogyakarta, 2019), pp. 472-478.

21. E. Istiyanti, E3S Web Conf. 232, (2021).

22. A. Charina, R. Andriani, B. Kusumo, A. H. Sadeli, and Y. Deliana, 14, (2018).

23. N. Kusnadi, N. Tinaprilla, S. H. Susilowati, and A. Purwoto, J. Agro Ekon. 29, 25 (2011).

24. A. Prayoga, Agro Econ. J. 28, 1 (2010). 
25. R. Sanjaya, Faktor Yang Mempengaruhi Adopsi Inovasi Petani (Angkasa Jaya, Surabaya, 2015).

26. S.A. Kennvidy, Int. J. Environ. Rural Dev. 1, 62 (2010).

27. T. L. Putri, D. A. H. Lestari, and A. Nugraha, J. Ilmu-Ilmu Agribisnis 1, 210 (2013).

28. A. Atman, J. Sains Agro 5, (2020).

29. R. Prasetyo, Planta Trop. J. Agro Sci. 2, 125 (2014).

30. T. C. Mendoza and D. Ph, J. Sustain. Agric. (2016).

31. E. M. Sari, A. I. Hasyim, and S. Situmorang, J. Ilmu-Ilmu Agribisnis 7, 6 (2019).

32. Badan Pusat Statistik, SKGB 2018 (PT Citra Mawana Patamaro, Jakarta, 2018).

33. Kusnanto, E. Maharani, and K. Shorea, Pekbis J. Vol 8, 14 (2016).

34. S. P. E. W.David Downey, Agribusiness Management (McGraw-Hill, Madison, 1987). 